\title{
Editorial
}

\section{Welcome to the New Journal-Hygiene}

\author{
Günter Kampf
}

check for updates

Citation: Kampf, G. Welcome to the New Journal-Hygiene. Hygiene 2021, 1, 41-42. https://doi.org/10.3390/ hygiene1010004

Received: 1 June 2021

Accepted: 2 June 2021

Published: 15 June 2021

Publisher's Note: MDPI stays neutral with regard to jurisdictional claims in published maps and institutional affiliations.

Copyright: (C) 2021 by the author. Licensee MDPI, Basel, Switzerland. This article is an open access article distributed under the terms and conditions of the Creative Commons Attribution (CC BY) license (https:// creativecommons.org/licenses/by/ $4.0 /)$.
Institute for Hygiene and Environmental Medicine, University Medicine Greifswald, Ferdinand-Sauerbruch-Strasse, 17475 Greifswald, Germany; guenter.kampf@uni-greifswald.de

It is an honor for me to accept the invitation of the role of Editor-in-Chief of $\mathrm{Hy}$ giene (https: / / www.mdpi.com/journal/hygiene). The new journal (ISSN 2673-947X) was recently created as an international, peer-reviewed, open access journal devoted to the publication of high-quality studies on all the different aspects of hygiene, including general hygiene, healthcare epidemiology, public health, and global and environmental health. Launching a new journal is a considerable task. The first months will be devoted to inviting top researchers, academics and scientists to consider Hygiene as one of "their journals". The journal is also still looking to further expand the editorial board to address the current gaps and further enrich the journal.

The COVID-19 pandemic has raised enormous public attention to all types of measures for the control of communicable diseases. A lot of research has been published already, and will continue to be published, on various aspects of SARS-CoV-2 control. At the same time, however, the global burden of healthcare-associated infections remains. The increase in antibiotic resistance may result in novel concepts to control the transmission of multi-resistant pathogens in various fields. Antiseptic tolerance towards some biocidal agents used for disinfection is increasingly found in selected bacterial species. The scientific community can currently see that it is important to carefully balance the expected health benefits from specific hygiene measure against the expected risks and consequences associated with its implementation. That is why I am glad that "health risk assessments" and "health policy implications" are part of the journal's scope. I very much hope that this journal can contribute substantial scientific value to the various aspects of hygiene.

The editorial board members and I cordially invite you to share your latest findings by submitting original research, reviews and/or proposals for Special Issues.

Conflicts of Interest: G.K. has received personal fees from Schumacher GmbH, Germany, for presentation and consultation. 


\section{Short Biography of Author}

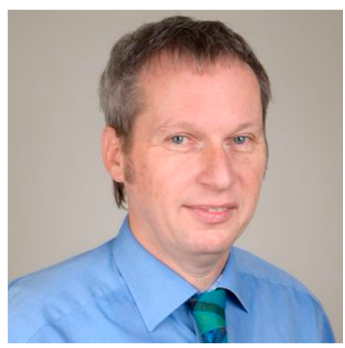

Günter Kampf studied medicine in Lübeck, Germany. He then worked in the United Kingdom in surgery, internal medicine and clinical pharmacology, followed by specialist training in hygiene and environmental medicine at the Free University of Berlin. He completed his habilitation at the University of Greifswald in 2003 and became associated professor there in 2009. From 1998 to 2016 he worked for Bode Chemie $\mathrm{GmbH}$, Hamburg, Germany, for the last 5 years as scientific director of the Bode Science Center. Since 2016 he has been self-employed as a specialist in hygiene and environmental medicine. He has published more than 220 scientific papers in mostly international journals, many book chapters and six text books. The scientific focus includes various aspects of healthcare epidemiology, hand hygiene, surface disinfection and resistance to active ingredients in disinfectants. 